Agric. Biol. Chem., 41 (1), 117 124, 1977

\title{
Preparation of Single Cell Protein (SCP) for Food and Improving of Its Spinnability
}

\author{
Isao Hayakawa and Danji Nomura \\ Laboratory of Food Process Engineering, Faculty of Agriculture, \\ Kyushu University, Fukuoka
}

Received July 21, 1976

\begin{abstract}
Experiments were carried out to establish a new method for the preparation of protein from single cell microbes combining an Impact-Cell-Mill (ICM) method with a technics of wet spun fiber formation, and also were studied on the relationship among viscoelastic properties, preparations and the spinnabilities.

The obtained results were as follows:

1) ICM method was superior to alkaline extraction method both in separation and yield respectively.

2) Yeast off-flavour of SCP prepared by ICM method was markedly decreased by employing a hot ethanol treatment. Dynamic modulus $\left(\mathrm{G}^{\prime}\right)$ of SCP caused an increase and a shift to high frequency side $(\omega)$ by employing a hot ethanol treatment, and the purity of SCP was improved by removing lipid and carbohydrate with present method.

3) SCP prepared by ICM method was found inferior to casein phase separation and spinnability. But its rheological properties and spinnabilities could be changed with the hot ethanol treatment. Present SCP showed a higher value in recovery and good coloring as a spun-fiber, but a decrease in nucleic acid contents by the spinning process. The dope in which nucleic acid content was markedly decreased showed good spinnability.
\end{abstract}

Necessities of researching on utilization of protein from single cell microbes have been pointed out in these days..$^{(\sim 4)}$

The possible use of microbial single cell protein as a new protein resources for human food has been receiving much attention nowadays. However, some adverse responses occur when large amounts of products are incorporated into human food. A large limitation to the use of SCP as a food source is controled by its high nucleic acid content. ${ }^{5,6)}$

Experiments are being carried out to establish a new method for the production of protein from Baker's yeast employing an ImpactCell-Mill (ICM) method ${ }^{15,16)}$ and a technics of wet spinning. Spun fibrous yeast protein is suitable for food. Because the nucleic acid content was below $2 \%$.

Kelley et al. ${ }^{71}$ Naismith, ${ }^{87}$ and Balmaceda et $a l .^{13)}$ studied the spinnability of soya protein and peanut protein. Ultracentrifugal examination of some proteins treated with various bases had been made. It has been shown that only bases with dissociation constants higher than $10^{-4}$ cause an appreciable reduction in the molecular weight of protein and are suitable for fiber formation with the protein.

Héden et al. $^{91}$ and Huang and Rha ${ }^{10)}$ studied on the spinnability of SCP from hot melt, and found that it could not be used for food directly, because it contains a lot of nucleic acid and some basic salts.

Authors studied on the relations among viscoelastic properties and spinnabilities of SCP prepared by ICM method, commercial casein and soya protein. Conventional SCP and soya protein were inferior to commercial casein in the spinning condition. Accordingly, for the improvement of its spinnability a great importance was suggested to increase strength of fiber in the spinning.

\section{MATERIALS AND METHODS}

Material and preparations. a) Baker's yeast was prepared from Saccharomyces cerevisiae (produced by 


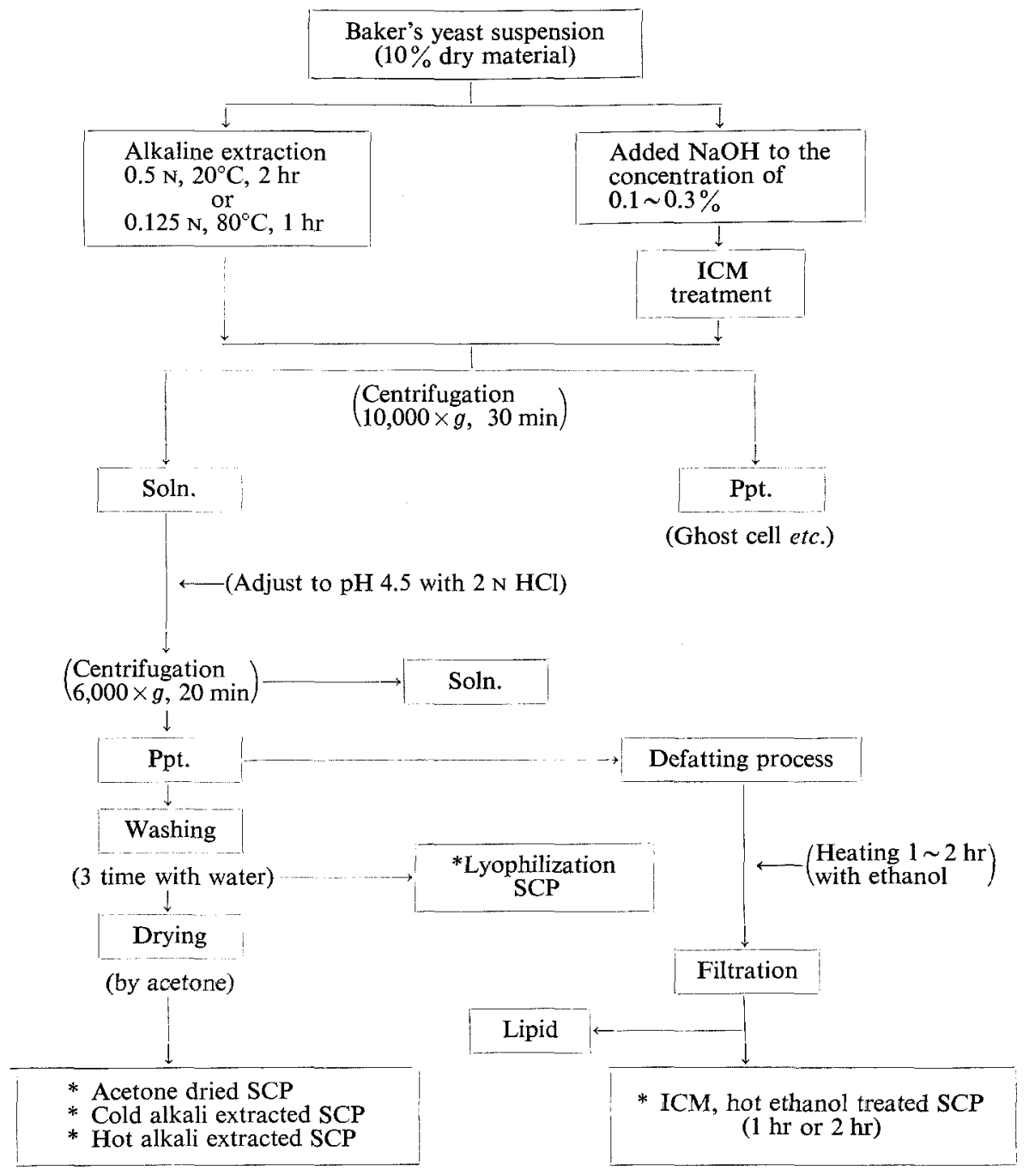

FIG. 1. Production Scheme of Yeast Protein.

Kanegafuchi Chemical Industrial Co., Ltd.) as shown in Fig. 1.

b) Soya protein was prepared from defatted soybean meal (produced by Showa Sangyo Co., Ltd.) as shown in Fig. 2.

c) A commercial casein was obtained from Ishizu Pharmaceutical Co., Ltd.

d) Spinning dopes were prepared by taking maturing time ( $5 \sim 120 \mathrm{~min}$ ) after adding $\mathrm{NaOH}$ (final concentration $0.9 \sim 2.4 \%$ ) to $10 \sim 25 \%$ protein suspension and heating $50^{\circ} \sim 80^{\circ} \mathrm{C}$.

Viscoelasticity measurement. Dynamic modulus $\left(\mathrm{G}^{\prime}\right)$ and loss modulus $\left(\mathrm{G}^{\prime \prime}\right)$ were calculated with Markovitz's equation. ${ }^{11)}$

Spinnability test. The spinnability of dope was measured by a trial spinning machine which was developed in our laboratory as shown in Fig. 3, with the following equipments, (1) hopper: volume $250 \mathrm{ml}$, thermoregulated, (2) nozzle: diameter $0.1 \sim 0.3 \mathrm{~m} / \mathrm{m}$, $1 \sim 15$ holes, $(3)$ coagulating vat: volume 8 liters, length $1500 \mathrm{~m} / \mathrm{m}$, made from a transparent vinyl chloride, (4) reel: velocity $10 \sim 100 \mathrm{~m} / \mathrm{min}$, in variable.

A commercial casein had been used as a standard material for spinnability test. The spinning condition was classified with a fiber formation in spinning.

Classification " $A$ " indicated the best fiber formation when the fiber could be reeled more than $35 \mathrm{~m} / \mathrm{min}$ with commercial casein. Alkali extracted SCP showed " $\alpha$," ICM treated SCP employing acetone drying showed "a," and ICM treated SCP employing a hot ethanol treatment showed " 1. ."

Classification " $B$ " indicated a condition that fiber 


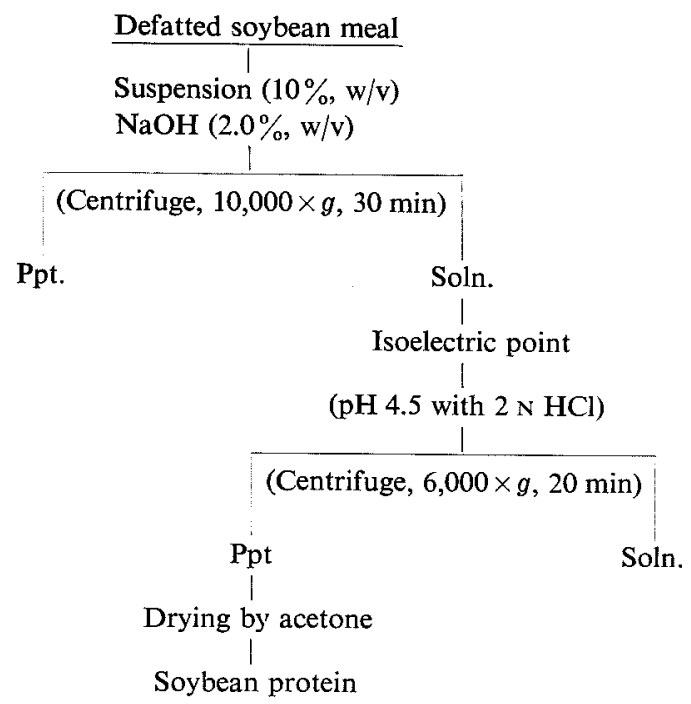

FIG. 2. Preparation of Soybean Protein.

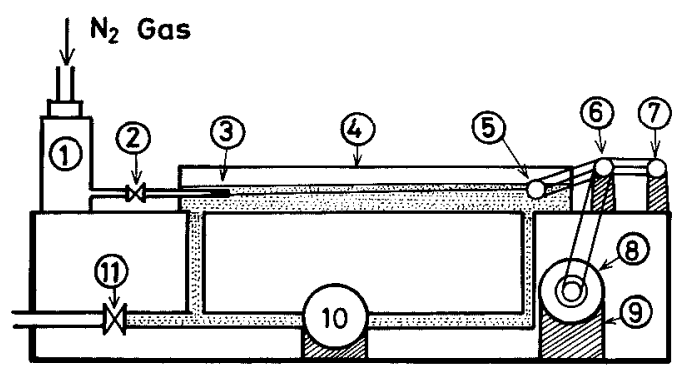

FIG. 3. Schematic Diagram of the Trial Spinning Machine.

(1) dope vat, (2) control valve, (3) spinneret, (4) coagulating vat, (5), (6) rolls, (7) reel, (8) rpm counter disk, (9) motor, (10) pump, (11) drain.

could be reeled with velocity slower than $35 \mathrm{~m} / \mathrm{min}$ with casein. Also " $\beta$ " in alkaline extraction method, " $b$ " in ICM treated SCP employing acetone drying, " 2 " in ICM treated SCP employing the hot ethanol treatment.

Classification " $\mathrm{C}$ " indicated a condition that a fiber could be made like a yarn, but could not be reeled with casein. Also " $r$ " in alkaline extraction method, " $c$ " in ICM treated SCP employing acetone drying, "3" in ICM treated SCP employing the hot ethanol treatment.

Classification " $D$ " indicated a gel formation as a dope did not resolve with casein, also " $\delta$ " in alkaline extraction method, "d" in ICM treated SCP employing acetone drying, " 4 " in ICM treated SCP employing the hot ethanol treatment.

Classification " $E$ " indicated a sol that the dope dissolved into a smaller molecularity, as this dope went to dispersion in the coagulation solution then flowed from a spinneret with casein, also " $\theta$ " in alkali extracted SCP, " $\mathrm{e}$ " in ICM treated SCP employing acetone drying " 5 " in ICM treated SCP employing a hot ethanol treatment.

Gel filtration of spinning dope. Sepharose $6 \mathrm{~B}$ was used to obtain the gel filtration chromatogram of these spinning dopes. A column of the Sepharose $(1.5 \times$ $90 \mathrm{~cm}$ ) was equilibrated with $0.076 \mathrm{M}$ Tris-citrate buffer (pH 8.6) containing $0.01 \mathrm{~m} 2$ mercapto ethanol and $0.4 \mathrm{M} \mathrm{NaCl}$. A flow rate $5 \mathrm{ml} / \mathrm{hr}$ was maintained by restricting a screw cock. Every $2 \mathrm{ml}$ aliquot was collected with a fraction collector and absorbance at $280 \mathrm{~nm}$ was measured with a Hitachi-Perkin Elmar $139 \mathrm{UV}$ Spectrophotometer using $0.5 \mathrm{~cm}$ light path.

\section{RESULTS AND DISCUSSION}

\section{SCP production methods and compositions}

ICM method is superior to an alkaline extraction method (hot or cold extraction) both in extraction and yield respectively. SCP that was extracted by a hot alkaline extraction method indicated about $94 \%$ and that was extracted by ICM method employing a hot ethanol treatment indicated $89.4 \%$ purity. Also it was about $81 \%$ when SCP was lyophilized. These values are shown in Table I.

However, SCP has a high nucleic acid con-

Table I. Analytical Data of Baker's Yeast Protein

\begin{tabular}{|c|c|c|c|c|c|c|}
\hline & \multicolumn{4}{|c|}{ ICM extraction } & \multicolumn{2}{|c|}{ Alkaline extraction } \\
\hline & Lyophilization & $\begin{array}{l}\text { Acetone } \\
\text { drying }\end{array}$ & $\begin{array}{c}\text { Hot e } \\
\text { treat } \\
(1 \mathrm{hr})\end{array}$ & $\begin{array}{l}\text { hanol } \\
\text { nent } \\
(2 \mathrm{hr})\end{array}$ & $\begin{array}{l}(0.5 \mathrm{~N}, \\
\left.20^{\circ} \mathrm{C}, 2 \mathrm{hr}\right)\end{array}$ & $\begin{array}{l}(0.125 \mathrm{~N}, \\
\left.80^{\circ} \mathrm{C}, 1 \mathrm{hr}\right)\end{array}$ \\
\hline Crude protein ${ }^{a)}$ & 80.4 & 87.0 & 86.8 & 89.4 & 81.7 & 94.2 \\
\hline Lipid $\left.^{b}\right)$ & 12.3 & 6.4 & 6.31 & 4.86 & 6.84 & 1.90 \\
\hline Carbohydrate $\left.^{c}\right)$ & 2.81 & 2.68 & 2.89 & 2.57 & 6.46 & 2.70 \\
\hline Ash & 4.17 & 4.00 & 3.91 & 3.25 & 5.00 & 1.20 \\
\hline Organic phosphorus $\left.{ }^{d}\right)$ & 1.13 & 1.09 & 1.43 & 1.36 & 0.933 & 0.978 \\
\hline
\end{tabular}


Table II. Influence of Preparations on the Coloring and Recovery

\begin{tabular}{|c|c|c|c|c|c|}
\hline & \multicolumn{3}{|c|}{ ICM extraction } & \multicolumn{2}{|c|}{ Alkaline extraction } \\
\hline & $\begin{array}{l}\text { Lyophili- } \\
\text { zation }\end{array}$ & $\begin{array}{l}\text { Acetone } \\
\text { drying }\end{array}$ & $\begin{array}{l}\text { Hot ethanol } \\
\text { treatment } \\
(1 \mathrm{hr})(2 \mathrm{hr})\end{array}$ & $\begin{array}{l}(0.5 \mathrm{~N}, \\
\left.20^{\circ} \mathrm{C}, 2 \mathrm{hr}\right)\end{array}$ & $\begin{array}{l}(0.125 \mathrm{~N}, \\
\left.80^{\circ} \mathrm{C}, 1 \mathrm{hr}\right)\end{array}$ \\
\hline O.D. 400 & 0.320 & 0.196 & $0.150 \quad 0.120$ & 0.326 & 0.328 \\
\hline Recovery & & $62 \%$ & & $17 \%$ & $32 \%$ \\
\hline
\end{tabular}

tent notwithstanding protein extraction method from single cell microbes in general. Especially, ICM method showed high value of nucleic acid content $20 \sim 30 \%$ than alkaline extraction method. Also the recovery in alkaline extraction method was small, an amount of SCP and nucleic acid extracted from single cell microbe showed a low value than ICM method.

Generally, by observing the degree of coloring of the obtained protein with five preparations obtained by combined methods of extraction and drying, it was seen that the hot ethanol defatted and dried preparation was the best one, giving light colored (O.D. ${ }_{400}=$ $0.120)$ material, the value was small as shown in Table II. Conventional SCP was colored in all alkaline extractions notwithstanding extraction temperature.

SCP prepared by ICM method has a strong off-flavour in general, but it showed less offflavour with the hot ethanol treatment.

On the other hand, the off-flavour is obscured by alkaline extraction in general.

Accordingly, ICM method shows about

TABLE III. Effect of Dope Components on the Spinnability

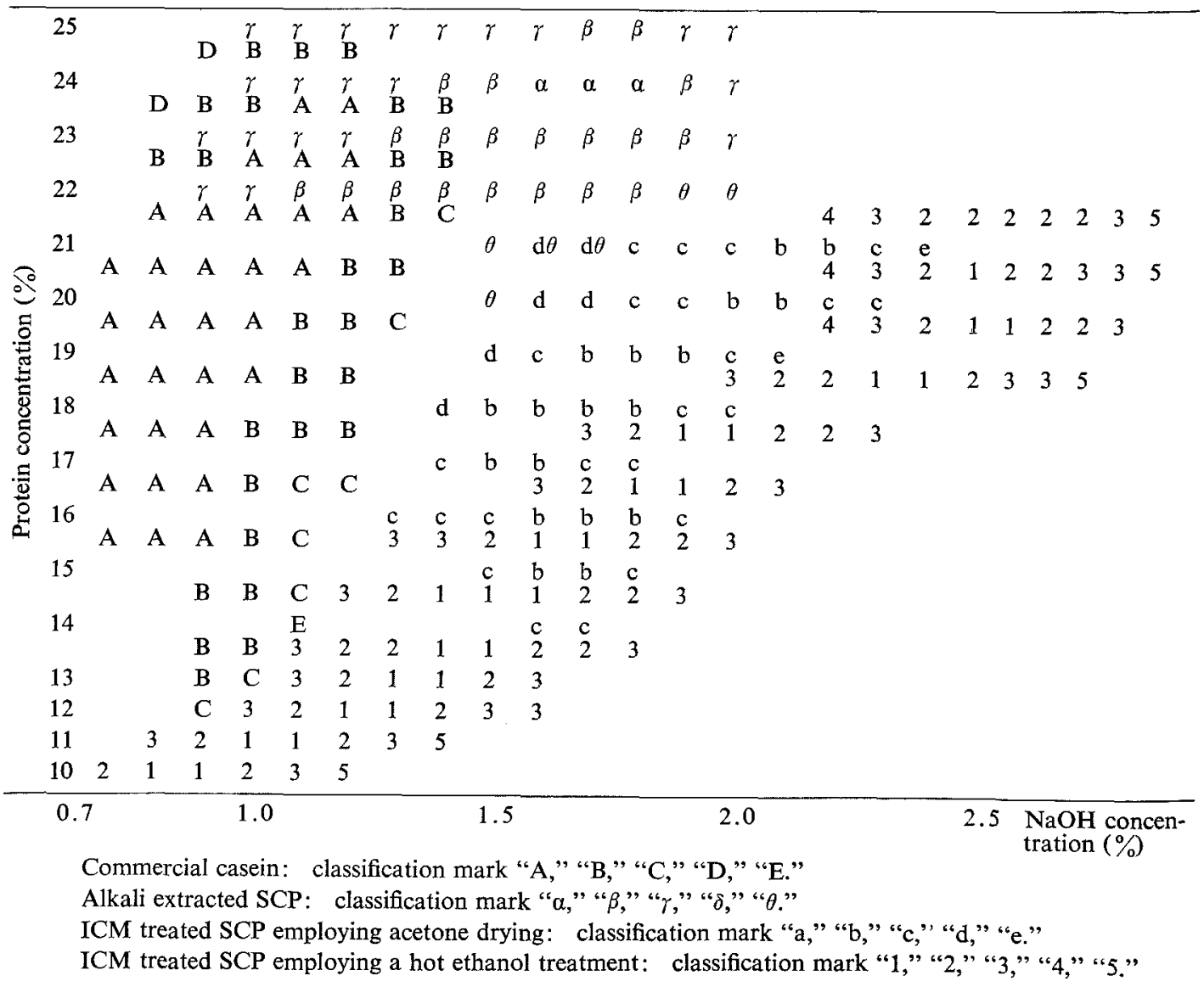


$62 \%$ of protein recovery with two times alkali extracted.

\section{Spinnability and dope composition}

The spinnability of SCP was measured with a trial spinning machine. The results are shown in Table III. Casein showed good results in many field in comparison with other protein as shown in Table III. Spinnability of the dope which was prepared by the hot alkaline extraction method resembled with casein. But the fiber could not be recovered as they were dissolved almost completely in water through washing process after spinning.

SCP prepared by ICM method employing a hot ethanol treatment could be spun like casein in a range from $10 \%$ to $13 \%$ protein concentration. Present spun fiber has a good elasticity, tenacity, and shows good fiber formation.

Distribution of molecular weight of SCP and casein

SCP showed some differences in spinnability according to the preparing and extracting processes of SCP. In order to know the differences in the spinnability of SCP, gel filtration (Sepharose $6 \mathrm{~B}$ ) was used to compared SCP with casein. The result is shown in

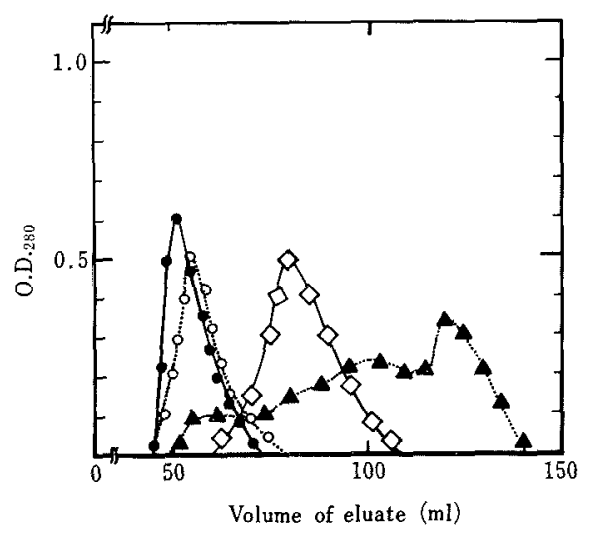

FIG. 4. Column Chromatograms of an ICM Treated SCP, an Alkali Extracted SCP, ICM and Hot Ethanol Treated SCP, and Casein with Sepharose 6B.

$\diamond-\diamond$, casein; $\bigcirc-\cdots$, ICM, acetone dried SCP; $\bullet-\bullet$, ICM, hot ethanol treated SCP; $\Delta \cdots \Delta$, hot alkali extracted SCP.
Fig. 4 , in this case, a $0.5 \%$ concentration of SCP was used. From the result in Fig. 4, SCP extracted by ICM method employing a hot ethanol treatment showed a peak at effluent volume of $52 \sim 56 \mathrm{ml}$. The dimension of the chromatogram behind the peak was comparatively larger, similar to that of SCP which was extracted by ICM method.

This SCP showed about Mw>600,000 (Kav $=0.095$ ), the molecular weight indicates a little increase after a hot ethanol treatment. On the other hand, a chromatogram of SCP that was extracted by hot alkaline solution for one hour showed a peak at effluent volume of 135 145 $\mathrm{ml}$, the dimension of the chromatogram before the peak was comparatively larger, its molecular weight was indicated to be about $\mathrm{Mw}=36,000(\mathrm{Kav}=0.722)$ a chrmatogram of casein showed a peak between SCP from ICM method and SCP from the alkaline extraction, its molecular weight was estimated to be about $\mathrm{Mw}=45,000(\mathrm{Kav}=0.636)$, and it will be seen that a casein has a limited distribution of molecular weight from a effluent pattern.

\section{Relation of $\log G^{\prime}$ and $\log \omega \cdot a_{\mathrm{T}}$}

After measuring the viscoelastic properties of spinning dopes, authors studied a hypothesis of "time-temperature reducibility" of spinning dopes, the criterion, the form of $\log a_{\mathrm{T}}$ as a function of temperature was applied first by noting that it was a smooth function with no gross fluctuations or irregularities and then by fitting the empirical values to an expression which has proved to be widely appliciable.

$$
\log a_{\mathrm{T}}=-\mathrm{C}_{1}(T-\mathrm{Ts}) /\left(\mathrm{C}_{2}+T-\mathrm{Ts}\right)^{14)}
$$

For this purpose, $(T-\mathrm{Ts}) / \log a_{\mathrm{T}}$ listed in previous paper ${ }^{12)}$ were plotted against $(T-\mathrm{Ts}$ ) and reduced to $T=30^{\circ} \mathrm{C}$ as Fig. 6 . These values were actually used in constructing Fig. 5 . From these results, there were some fundamental difference between the dope of casein and the dope of SCP. From the slope S of strage modulus of spinning dopes against frequency reduced to $30^{\circ} \mathrm{C}$.

When a slope $\mathrm{S}$ showed a change in a limita- 


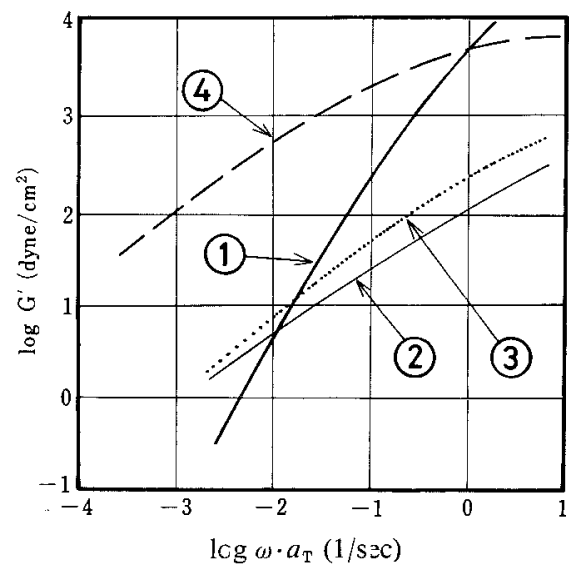

FIG. 5. Storage Modulus of Spinning Dopes against Frequency Reduced to $30^{\circ} \mathrm{C}$.

(1) casein, protein concentration $20 \%, 0.9 \% \mathrm{NaOH}$; (2), hot ethanol treated SCP, protein concentration $16 \%, 1.6 \% \mathrm{NaOH}$; (3), hot alkali extracted SCP, protein concentration $24 \%, 1.7 \% \mathrm{NaOH}$, (4), acetone dried SCP, protein concentration $20 \%, 2.0 \% \mathrm{NaOH}$.

tion from $1 / 2$ to 2 against frequency, the dope showed a "rubber-like flow" by the spectrum of dynamic modulus. Thus, this behavior was like an uncross-linked polymers. It is superior to spin as casein takes a single dispersion in this rubber-like flow, but a slope S of SCP showed a small value than slope $S$ of casein. There were no fundamental difference among the dopes of SCP that were prepared from ICM method combined with a hot ethanol treatment or alkaline extraction, etc.

As the spectrum of dynamic modulus of SCP shifted to high frequency side with the hot ethanol treatment. So the molecule of SCP appeared to be combined as subunits or subchains by the hot ethanol treatment.

\section{Relation of tan $\delta$ and $\log \omega \cdot a_{\mathrm{T}}$}

The relation of preparation methods of SCP and $\tan \delta$ are shown in Fig. 7. The spinning dope made from casein shows the transition zone that a rubber-like flow changes into rubber-like elasticity against increasing the frequency $(\omega)$ in the limitation from -1 to 1 , but a dope of SCP which was prepared by ICM method employing acetone drying had no transition zone from a rubber-like elasticity

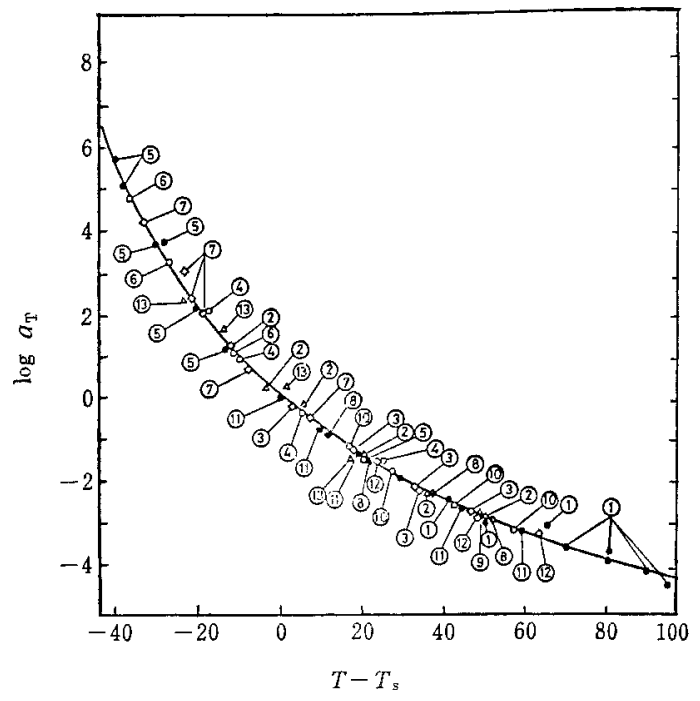

FIG. 6. Temperature Dependence of Shift Factor $a_{T}$ Used in Previous Paper, Chosen Empirically; Curve, from WLF Equation. ${ }^{14)}$

\begin{tabular}{|c|c|c|c|c|c|}
\hline No. & Sample & Protein & $\mathrm{NaOH}$ & Mark & $\mathrm{Ts}\left({ }^{\circ} \mathrm{C}\right)$ \\
\hline 1 & Casein & 20.0 & 1.0 & 0 & -45.0 \\
\hline 2 & $\begin{array}{l}\text { Casein } \\
\text { M. yeast } \mathbf{P}\end{array}$ & $\left.\begin{array}{l}10.0 \\
10.0\end{array}\right) \mathrm{mix}$ & 1.0 & $\triangle$ & 8.0 \\
\hline 3 & Casein & 26.0 & 1.0 & 0 & 21.0 \\
\hline 4 & Casein & 24.0 & 1.0 & 0 & 24.0 \\
\hline 5 & $\begin{array}{l}\text { Soy bean } \\
\text { protein }\end{array}$ & 18.0 & 2.1 & - & 43.0 \\
\hline 6 & $\begin{array}{l}\text { Soy bean } \\
\text { protein }\end{array}$ & 18.0 & 1.9 & 0 & 41.5 \\
\hline 7 & $\begin{array}{l}\text { Soybean } \\
\text { protein }\end{array}$ & 18.0 & 1.8 & 0 & 37.8 \\
\hline 8 & $\begin{array}{l}\text { Soybean } \\
\text { protein }\end{array}$ & 20.0 & 2.0 & $\diamond$ & -6.5 \\
\hline 9 & $\begin{array}{l}\text { Soybean } \\
\text { protein }\end{array}$ & 18.0 & 2.2 & $\triangle$ & -102.0 \\
\hline 10 & $\begin{array}{l}\text { M. yeast } \\
\text { protein }\end{array}$ & 18.0 & 1.8 & 0 & -12.0 \\
\hline 11 & $\begin{array}{l}\text { M. yeast } \\
\text { protein }\end{array}$ & 18.0 & 1.4 & - & -14.0 \\
\hline 12 & $\begin{array}{l}\text { M. yeast } \\
\text { protein }\end{array}$ & 18.0 & 1.2 & 0 & -18.0 \\
\hline 13 & $\begin{array}{l}\text { M. yeast } \\
\text { protein }\end{array}$ & 20.0 & 1.5 & $\triangle$ & 27.5 \\
\hline
\end{tabular}

to rubber-like flow. These phenomena are unsuitable to spin a fiber formation. On the other hand, a dope of SCP which was prepared by employing the hot ethanol treatment showed a viscoelastic properties as well as alkaline extraction protein, the dynamic modulus increased along with frequency $(\omega)$ but less than casein. 


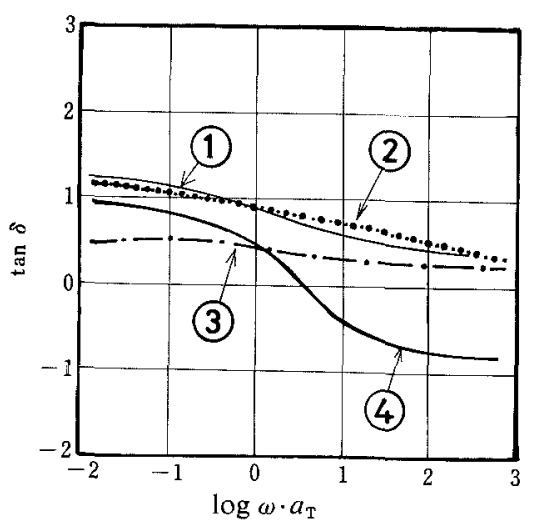

FIG. 7. Relation between $\tan \delta$ and Kinds of Protein Reduced to $30^{\circ} \mathrm{C}$.

(1), ICM treated SCP employing a hot ethanol treatment; (2), alkali extracted SCP; (3), ICM treated SCP employing acetone drying; (4), commercial casein.

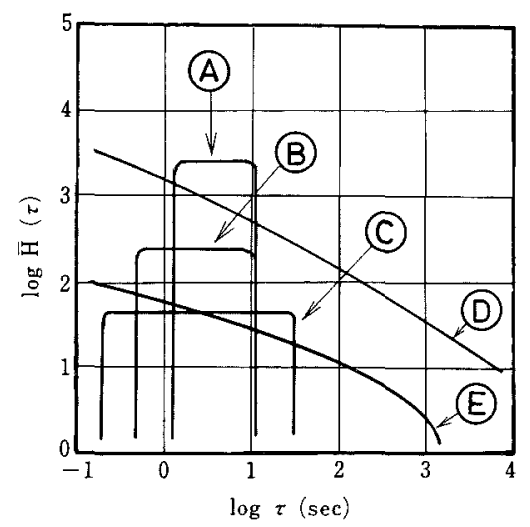

FIG. 8. Relaxation Spectrum of Spinning Dopes. (A), dope "A," " 1 "; (B), dope "B," "b," "2"; (C),

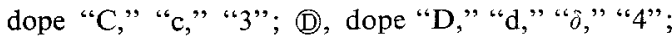
El, dope " $\beta$," " $\gamma$. ."

\section{Relaxation spectrum of spinning dope}

The relaxation spectrum of spinning dope shows a typical box type where the dopes have a good spinnability as shown in Fig. 8. Especially, a dope that has good spinnability shows a spectrum like type "A" in Fig. 8. The dope of SCP that was prepared by ICM method shows a spectrum like the type " $B$ " usually, but these spectra change from type " $B$ " to type "A" by employing the hot ethanol treatment in protein concentration about $10 \sim 13 \%$. It is consider single dispersion to show the spectrum like type "A."
In the hot alkaline extraction protein, the spectrum usually shows a spectrum like type "E," from these phenomena, this molecular distribution is considered to be wide and multi dispersion. Thus, ICM method is superior to prepare SCP for spinning than alkaline extraction.

SCP that was prepared by ICM method was inferior to casein in the phase separation and spinnability. But SCP could be changed in rheological properties and spinnabilities by employing the hot ethanol treatment. SCP prepared by this method showed a high recovery and good coloring as a spun fiber, and nucleic acid content was decreased below $2 \%$ by the spinning process. The analytical data are shown in Table IV. The dope that nucleic acid content is largely on the decrease shows good spinnability in general.

Table IV. Analytical Data of Spun-Fiber Yeast Protein

\begin{tabular}{lcc}
\hline & $\begin{array}{c}\text { Classification "1" } \\
\text { (good formation) }\end{array}$ & $\begin{array}{c}\text { Classification "3" } \\
\text { (nonphase separation) }\end{array}$ \\
\hline Crude protein $^{a)}$ & 92.0 & 89.1 \\
Lipid $^{b}$ ) & 4.38 & 4.12 \\
Carbohydrate $^{c)}$ & 0.45 & 1.07 \\
$\quad$ RNA $^{d)}$ & 1.12 & 4.34 \\
Ash & 1.31 & 1.30 \\
\hline
\end{tabular}

a) Lowry's method.

b) Chloroform-methanol mixture $(1 ; 1)$.

c) Phenol-sulfuric method.

d) The proposed modification of Allen's method: (total phosphorus) - (non organic phosphorus).

\section{REFERENCES}

1) B. Laine, "Text of Paper Presented at the Second International Conference on Global Impacts of Applied Microbiology," ed. by B. Laine, Laboratory of Microbiology, S. F. BP. Lavera, France, 1967, pp. $1 \sim 18$.

2) G. Hedenskog and L. Enebo, Biotechnol. Bioeng., 11, 37 (1969).

3) J. G. Brookman and M. Davies, ibid., 15, 693 (1973).

4) A. E. Humphrey, "Engineering of unconventional protein production," ed. by H. Bieber, American Institute of Chemical Engineers, New York, 1969, pp. $67 \sim 71$.

5) J. C. Edozien, U. U. Udo, V. R. Young and N. S. Scrimshaw, Nature, 228, 180 (1970). 
6) S. Ohta, S. Maul, A. J. Sinsekey and S. R. Tannenbaum, Appl. Microbiol., 22, 415 (1971).

7) J. J. Kelley and R. Pressey, Cereal Chem., 43, 195 (1966).

8) W. E. F. Naismith, J. Appl. Chem., 4, 188 (1954).

9) C. G. Héden, N. Molin, U. Olsson and A. Rupprecht, Biotechnol. Bioeng., 13, 147 (1971).

10) F. Huang and C. Rha, ibid., 14, 1047 (1972).

11) H. Markovitz, J. Appl. Phys., 23, 1070 (1952).

12) I. Hayakawa, S. Kawasaki and D. Nomura,
Nippon Nôgeikagaku Kaishi, 49, 641 (1975).

13) E. Balmaceda and C. Rha, J. Food Sci., 39, 226 (1974).

14) J. D. Ferry, "Viscoelastic Properties of Polymers," ed. by J. D. Ferry, John Willy \& Sons. Inc., New York, 1970, pp. 314 320 .

15) I. Hayakawa and D. Nomura, J. Fac. Agr., Kyushu Univ., 17, 289 (1973).

16) I. Hayakawa, N. D. Khai and D. Nomura, J. Ferment. Technol., 51, 677 (1973). 